\title{
On the Importance of Theory in LIAS: A Review of Literature on Radical Librarianship in Canada
}

\author{
Carolin Huang \\ University of Alberta \\ carolin1@ualberta.ca
}

\begin{abstract}
With the decline of social services in welfare states, libraries have come to represent the final frontier of democracy amongst privatizing public institutions. This view of libraries is especially prevalent in the media but is more carefully analyzed in critical LIAS (library, information, and archival studies). Because of the urgency of the position that librarianship holds in our society, social-justice-oriented perspectives have flourished in the library setting. This paper overviews the state of radical librarianship in Canada through a collection and analysis of resources on said subject. It argues for the importance of theoretical thinking in radical librarianship, that challenges the epistemological paradigms that dominate LIAS and acknowledges the ongoing institutional violence perpetuated by the library and information sector. With respect to the value of intellectual labour, the intention of this paper is to encourage further inquiry into the subject of radical librarianship so as to continue nurturing these pockets of dissent.
\end{abstract}

\section{Introduction}

With the decline of social services in welfare states, libraries have come to represent the final frontier of democracy amongst privatizing public institutions and as a result, take on new responsibilities that once belonged to these institutions. This view of libraries is especially prevalent in the media, where libraries are being discussed as both the means to defend democracy and the emblem of democracy (see vanden Heuvel, 2018; Anderson, 2018; Halpern, 2018; Pateman, 2019; Zeman, 2018; Klinenberg, 2018). Critical library, information, and archival studies (LIAS) scholarship takes these claims further by adopting a self-reflective approach on the profession and examining the possibilities that emerge from its charged place in contemporary society. While reflection on and examination of librarianship have always been informed by sociopolitical and geographical context, certain strains of critical LIAS scholarship and practice have veered toward a more radical direction, looking at how librarianship contributes to or combats more fundamental inequality in our society. Thus with the growing reputation of librarianship with social change in society (Gregory \& Higgins, 2013, p. 2; Samek, 2007, p. 8; Morrone, 2014, p. 3; Gray, 2012, p. 43), sharing principles on and experiences of radical librarianship is much needed.

The notion of radical librarianship is of course not a straightforward one. It does not entail a teleological direction towards justice or progress, and instead, encompasses the many ways 
librarianship both contributes to and subverts power. It forefronts the tensions that librarianship faces through questions of democracy, political economy, public space, progress, colonization, and intellectual freedom, integral to the everyday operations of libraries and archives. As Yoder (2003) has argued, the metanarrative of progress can further divide the privileged and the marginalized in the library and information setting (p. 383). If value is inscribed based on progress, it cements a hierarchical relationship between those deemed not advanced enough and those setting the terms of progress. In this paper, the term radical librarianship will be used to encompass other all left-leaning, non-traditional forms of librarianship that are named elsewhere: progressive librarianship, critical librarianship, socially responsible librarianship and activist librarianship, but will abide by the position that librarianship is full of contradictions. Toni Samek (2004) describes some of the defining features of progressive librarianship as: rejection of political neutrality, support for intellectual freedom, coalition-building, participatory decisionmaking, opposition to the commodification of information, advocacy for the accessibility of information, promotion of cultural diversity, prioritization of people over capital, and defense of democratic values (p. 12). I hope to complement this list by referring to the importance of reflection and theorizing, discussed in the work of David Hudson, and the dualistic nature of librarianship in both disciplining and mobilizing populations, revealed through the use of Foucaultian and Habermasian thought in LIAS. These additions prevent the erasure of "impractical" intellectual labour contributed by LIAS and ongoing institutional violence perpetuated by the information sector. The choice to use the term "radical" in this paper and project is in part to its association with identifying root issues that inform power structures in society. The Journal of Radical Librarianship frames radical librarianship around "the ethical roots of librarianship" (Lawson, 2015, p. 1) and the Radical Librarian Collective, which formed in London, UK in response to the increasing neoliberalization of the library and information environment, uses the term radical because they see libraries as "growing, rooted organisms whose collections and services shift and expand according to their changing usage" and "radical entities via the people who organise, tend, and facilitate their usage" (Arkle, Brynolf, Clement, Corble, \& Redgate, 2016, p. 2-3). For Lankes (2016), the term "radical" simply means invoking thought and action in a profession that has become predominantly passive (p. 6). The movements that are enabled by a framework of radicality are the groundings from which this paper develops.

This paper serves as further reflection on the state of radical librarianship, through an overview of a project on collecting resources on radical librarianship in Canada. It traces the process and challenges of creating a collection on the state of radical librarianship in the Canadian setting, from the formation of the CLA in 1946 to the present day. In so doing, it offers a literature review on the topic and makes visible the obvious gaps in this body of literature. Discussions on radical librarianship have largely focused on the US and the UK, even though many such discourses and events have affected the library and information field in Canada. By bringing in resources from different intellectual settings and locations into one place, this collection intends to add to the history of radical librarianship, highlight dissent and activism in the field, and stimulate further intellectual production on the subject.

Journal of Contemporary Issues in Education, 2020, 15(1), pp. 4-21. 
To provide more context for the collection, this paper begins with the history of radical librarianship. It then summarizes the process of creating the collection, reviews the current literature specific to Canada and offers points of reflection.

\section{Historical Context}

Librarianship has had a long history driving societal transformation as Bales (2018) argues that modern librarianship, arising out of principles of liberal democracy, has always been committed to the development of public life ( p. 7). While he posits that the library institution's drive towards social advancement was rooted in the investment of liberal democratic society in justice and equality (p. 8), he also contends that libraries are spaces of contention for upholding social justice due to their investments in institutionalized neutrality (p. 13).

The history of Canadian librarianship upholds these claims, given that the beginning of librarianship in Canada is attributed to the personal libraries of historians and settlers and libraries of Jesuits in the 17th century (Peel, 1982-1983; Beckman, Dahms, \& Bruce, 2015; Burpee, 1908). By the 18th and 19th centuries, libraries were found at settlements and fur-trade and military posts, and during the 19th century, mechanics' institutes, school libraries, professional libraries, and subscription-based public libraries became more prominent (Beckman, Dahms, \& Bruce, 2015, para. 3). It was only until the late 19th century that the first free taxsupported public libraries emerged (Beckman, Dahms, \& Bruce, 2015, para. 4). In this way, the growth of libraries and librarianship in Canada generally aligned with the sociopolitical and economic activities of its time and was never intended to be a subversion against dominant society. The only exception is the province of Quebec, where public libraries were established later than the rest of Canada due to the public perception of libraries as a threat to the Catholic Church (Picco, p. 140-141).

Although libraries continue to be regarded as symbols of democracy in the media, the relationship between democracy and libraries has been debated in academic scholarship (see Buschman, 2018; Wiegand, 2011; Frohmann 2004; Buckland, 2008). Buschman (2005) discusses the state of crisis that librarianship has been facing, linking it to the fate of all public cultural institutions, where economics has become the grounds for decisions affecting these institutions. A business-centred philosophy has taken over the public sphere and has prevented libraries from reaching their democratic ideal of "unfettered communication and investigation" (Buschman, 2005, p. 9). Pushing beyond surface-level representations of libraries as democratic, more radical critiques drawing on critical theory have been formed. The activist nature of the profession and the illusion of neutrality are prominently discussed in literature about radical librarianship (Gregory \& Higgins, 2013, p. 2; Samek, 2007, p. 8; Morrone, 2014, p. 3). To highlight the relationship between librarianship and social action, Samek (2007) has compiled examples of how librarians have practiced manifestations of social action like anarchism, campaigns, infiltration, mass direct action, and solidarity (p. 47), and how librarians have 
employed their own strategies specific to the library and information field to resist dominant ideologies (p. 67).

Samek (2004) argues that literature on the subject has generally been lacking despite the flourishing of library activism with the Internet (p. 2). In her own work, she has traced the roots and growth of progressive librarianship as it emerged in the US context. She uses the term "progressive librarianship" to refer to socially responsible librarianship, activist librarianship, and radical librarianship, as it is used in the North American context, and critical librarianship, as it used in the European context (Samek, 2004, p. 2). She locates the origins of progressive library discourse to the 1930s in the American Library Association (ALA) when issues of peace, segregation, library unions, and intellectual freedom were being brought to the table by younger members (Samek, 2004, p. 3). From this point onwards, there were two major waves of momentum building for progressive librarianship, one in the 1960s in response to global social movements and the increased concern with social responsibility in the field of librarianship and the other in the 1990s with the rise of the Internet. For Samek, intellectual freedom for librarians was a crucial issue from the very beginning, since the nature of advocacy and activism requires freedom of expression (Samek, 2004, p. 4). Its importance is especially reflected in the plethora of alternative library publications that came out in the 60s and 70s (Samek, 2004, p. 4). In the Canadian setting, intellectual freedom was the foundation of the Canadian Library Association's (CLA) founding ethical philosophy (Samek, 2002, p. 37).

Consistent with the research on the limited historiography of librarianship in Canada (McNally, 1986, p. 452), the specific origins of radical librarianship in Canada are not well documented. McNally (1986) attributes the dearth of Canadian library history to Canada's historiographical tradition on nationalism and independence (p. 451). In both Canadian English-language historical writing and French-language English writing, biography and political history have been prioritized over cultural history (McNally, 1986, p. 451). Rather than employing historiography, literature on radical librarianship in Canada has focused more on analyzing events in the contemporary context. The work on radical librarianship in Canada is also more scattered, lacking any essential text that offers a comprehensive history of radical librarianship specific to Canada. However, there has been a rise in literature on community-led librarianship, a social justice approach to librarianship that was conceived in the UK and Canada to address social exclusion and prioritize the needs of low income and excluded communities in public libraries (Pateman \& Williment, 2016). Through what was called the Working Together Project (2004-2008), Vancouver, Regina, Halifax and Toronto public libraries explored the practice of community-led librarianship, identifying the barriers to libraries faced by socially excluded communities, building relationships with these communities to improve library services and developing of an inclusive service planning model. The Edmonton Public Library later developed their own community-led librarianship model from 2006 to 2010.

While intellectual freedom has been at the foundation of the history of progressive librarianship, for Birdsall (2006), a progressive librarianship that only encompasses intellectual freedom does

Journal of Contemporary Issues in Education, 2020, 15(1), pp. 4-21. 
not attend to the contemporary transformations in communication (p. 50). In his analysis, he emphasizes the importance of communication in defining progressive librarianship because there have been major transformations in global electronic communication. He states that "[i]t shifts the focus of the library from information to communication, from content to process, from the informed citizen to the communicative citizen" (Birdsall, 2006, p. 61). The relational aspect of social action is thus essential to contemporary progressive librarianship.

Samek also addresses how progressive librarianship is currently being practiced and has branched from central concerns surrounding intellectual freedom. She overviews the ways in which the Internet is being used as a tool for activism but also calls for a critical outlook on Internet and information technologies (Samek, 2004). This move towards digitalization in librarianship gives rise to information ethics, global information justice, and intercultural information ethics as important concepts, where the breaking down of barriers needs to be balanced with recognizing cultural diversity, especially for Indigenous populations (Samek, 2004, p. 10). Placing the issue of cultural diversity at the core of contemporary librarianship, Samek (2007) notes how certain communities, such as Indigenous peoples, women, and political radicals, have always been excluded from cultural institutions (p. 13). Globalization and digitization have become major threats to cultural diversity, so it is particularly important for library and information workers to be wary of the sociopolitical transformations happening around them (Samek, 2007, p. 15). As Samek (2007) states: "Twenty-first century librarianship that focuses on values such as human dignity, freedom of expression, social responsibility and cultural diversity is vulnerable to the push and pull of competing ideological, economic, technological, legal, political, cultural and social agendas" (p. 16).

Similarly, Hudson (2012) is wary of the Western biases and knowledge frameworks that are taken for granted in narratives of global information inequality and the digital divide, arguing that LIS, in its concern for global equality, has employed dominant international development discourses. He states that what constitutes information, technology, and knowledge is always determined by Western states, so that the West is always advanced in these areas, and the nonWest is always underdeveloped and needing of guidance (Hudson, 2012, p. 76). Indigenous communities are especially impacted by narratives of global information inequality as they are presumed to be static cultures that need Western technologies to advance (Hudson, 2012, p. 80). In putting into question major concepts that drive the work of librarianship, Hudson advocates for continuous self-reflexivity and critical reflection in the field, even when it has good intentions.

Radical librarianship, thus, must operate on a philosophical level, asking deeper questions, as solely pragmatic approaches operate on presumptions and dominant ideologies (Hudson, 2012, p. 84). Hudson (2016) expands on these ideas in a lecture called "On Critical Librarianship \& Pedagogies of the Practical," where he articulates the ways in which critical LIS continues to assume the primacy of practicality as a pedagogical method. He pulls apart the common narrative about theory as elitist and removed from the real world, noting that the call to everyday, 
limpid language often assumes the neutrality of speech and as a result, affirms dominant discourse (Hudson, 2016). How theory is produced in the intellectual life of marginalized people is neglected when presumptions about what theory is and what it can do persist. He hones in on the language of diversity and inclusion in LIS, which he argues, locates the problem of race to the lack of diverse representation in the workforce as opposed to the larger structure of racism that gives rise to these localized forms of racism (Hudson, 2017, p. 11). Because these unquestioned concepts on theory and language maintain the status quo of white supremacy in the library world, he argues for forming LIS spaces that go beyond solution-oriented scholarship and ordinary language. In the growth of LIAS literature on radical librarianship in Canada, these major shifts in approaches and thought must be acknowledged, addressed, and responded to. The underlying thread is this paper, then, is to expand Hudson's project, to "move from a politics of purity to a politics of social critique, .... a practice, indeed, that understands the value of examining, unpacking, and traversing such boundaries in the first place” (Hudson, 2017, p. 27)

\section{The Collection}

The collection of resources on radical librarianship takes the form of a website and is available to the public. It is catered to librarians/archivists/information professionals, LIAS scholars, master's students in the fields of library, information and/or archival studies, and others interested in radical librarianship in the Canadian setting, and includes a variety of resources that range from more theoretical analyses to personal reflections. The multiplicity of formats included--social media, academic articles, blogs, books, and other web resources--allows for different levels of inquiry into an underrepresented history and a wider range of voices reflecting on the subject. Out of all the resources I gathered, I created a short list, prioritizing theoretically strong and pertinent articles that touch on issues of decolonization, anti-racism, neoliberalization and proactive struggle (see Appendix).

This collection of resources does not strive for completeness, not only because of the underdocumented nature of such work and the ongoing struggles against power structures, but because of the inevitable omissions in every collection (Carter, 2006, p. 216). The desire for obligatory inclusion of all subjects cannot be fulfilled given that any collection is predicated upon a selection process. Furthermore, Carter (2006) has called attention to how the practice of filling in all gaps may actually oppose the subversive acts of those who refuse to be included in erasing the ongoing violence enacted upon particular groups (p. 227). He uses the example of women who have been historically left out of the archive deciding not to be included postexclusion (Carter, 2006, p. 227). Their politics of refusal insists on the power of silence and rejecting further marginalization. For Foucault (1972), discontinuities play an essential role in the history of ideas and the production of knowledge, and to pretend otherwise is to sustain the naive assumption that "human consciousness [is] the original subject of all historical development and all action" (p. 12). Thus, a radical methodology of collection development should not assume that a collection can be exhaustive and should instead incorporate an acknowledgement of its absences. A reading of the absences serves to bring attention to 
continued injustice, as absences enact a haunting, reminding us of the asymmetrical grounds for memorialization and documentation. The collection holds both important ideas that speak to the challenges of today's information setting and major gaps that demonstrate the work that still needs further consideration. As threats to the existence of librarians and librarianship become more and more prominent, these critical voices and silences become evermore meaningful.

For the search and selection process of the collection, I used the different combinations of the search terms "librarianship", "librarian", "library", "radical", "activist", "progressive", "critical", "social justice", "social movement", "activism", "feminist", "queer", "indigenous", "LGBT", "anti-racist", "disability", "homelessness", "poverty”, "intellectual freedom”, "Canada", "Canadian" to specify that I was looking for resources specific to the library profession, geographically based in Canada, and social justice related. I searched through the databases: Google Scholar, University of Alberta Libraries, EBSCO, SAGE, ScienceDirect, Taylor \& Francis Online, Project MUSE, Emerald, and JSTOR; through specific journals: Progressive Librarian, Journal of Radical Librarianship, Journal of Critical Library and Information Studies, Library Trends, Under the Lead Pipe, Archivia, Feliciter, Journal of Canadian Academic Librarianship, Partnership: The Canadian Journal of Library and Information Practice and Research, and Canadian Journal of Information and Library Science; and through works' bibliographies. To access non-academic resources, I used Google and Twitter to seek out resources.

Because there is already a scarcity of work completed on the topic of radical librarianship, finding work specific to Canada was a challenge. For this project, the rubric of radical librarianship encompassed works that did not name the concept/practice as long as the work employed critical analyses and/or discussed non-traditional practices. Following the work of Hudson, it aims toward a theoretically-grounded radical librarianship that moves beyond thoughtless prescriptive performance. Because alternative theoretical approaches to library history have been heavily influenced by Foucault and Habermas (Popowich, 2007), I considered how radical librarianship can both be a mode of critique and an orientation towards new possibilities. The work of Habermas lends well to LIAS discourse because it is concerned with the formation of the public sphere from the 17th to 19th centuries as a place of debate for the bourgeoisie. For Popowich (2007), Habermas' work demonstrates how the transformations in the economic system at the time helped form the public sphere, used at the time to exclude or control working class populations. Yet because Habermas had hope for the possibility of emancipation through freedom of expression, Habermas' work is used to speculate the possibilities that radical librarianship can open up. Foucault's work, on the other hand, traces the genealogy of the Enlightenment project as repressive instead of progressive, and its institutions as structures of domination. Thus, it serves well in exposing the dominant ideologies that public libraries uphold. This dual consideration provides for both a self-reflexivity towards libraries as institutions of control and producers/reinforcers of dominant discourse, following a Foucauldian lens, and a possibility that open discussion can be fostered within these institutions, following a Habermasian lens.

Journal of Contemporary Issues in Education, 2020, 15(1), pp. 4-21. 


\section{Themes \& Absences}

From what I found, there were few books compared to the wide range of academic articles. As a result, there is much breadth, and less depth in the body of literature, in that much of the literature reflects on one-off experiences and less so develops long-term historical and structural analysis. These findings affirm Hudsons's (2017) observations on the precedence of pragmatic concerns and common sense language in LIS. Practicality and common sense are of course in themselves not the problem; the problem is when non-productive and non-solutions-oriented forms of knowledge are deemed superfluous or irrelevant. As much as I attempted to find work that was more conceptual in nature in my choice of search terms, the dearth of such work became apparent. Some articles were found in more para-academic settings such as library association blogs and Public Libraries Online. There was a prominence of Twitter use and blogging by radical librarians, which stresses the importance of the Internet as a platform for dialogue. The hashtags \#critlib and \#radlibchat are especially indicative of the significance of online advocacy as a tool for radical librarianship. The authors of the literature are varied, from MLIS students/recent graduates to LIAS academics to practicing librarians and archivists.

With regard to the content, key themes that stand out include: increased cuts to library and archives, neoliberal discourse in library associations and policies, unionization at academic libraries, decolonization of library education and practice, the absence of Indigenous and people of colour librarians, librarianship as a feminist profession, the effects of postmodernism on archives, archiving of marginalized histories, social exclusion perpetuated by the profession, intellectual freedom for the library profession, advocacy for diversity in hiring and collections, and community-led librarianship. Two major events that have shaped contemporary radical librarianship in Canada are the cuts to Library and Archives Canada and the release of the Truth and Reconciliation Commission (TRC) Report. Other shaping factors include the broader structures of neoliberalism, racism, and homo/transphobia, in addition to the debates on homelessness, Internet censorship, and technological innovation that has preoccupied the entire field of librarianship.

Other events and perspectives that are well covered by this body of literature include the history of activism in academic librarianship and the neoliberalization of library discourse and practice. Activism in the academic library setting has been noteworthy in Canada, and thus the book In Solidarity: Academic Librarian Labour Activism and Union Participation in Canada (see Annex below) provides for an informative account of that history. Issues regarding the profession of librarianship, such as unionization, economic parity, status and labour rights, are thoroughly documented in the literature on academic librarianship. Some historical and contemporary events relating to intellectual freedom for academic librarians in Canada are overviewed. Affective labour and feminist leadership are also subjects that have also been relevant to the academic library setting.

Journal of Contemporary Issues in Education, 2020, 15(1), pp. 4-21. 
The events surrounding Library and Archives Canada (LAC) are also well discussed and analyzed by LIAS scholars in Canada. Scholars discuss how the rhetoric of digitization was deployed to justify the casualization and deprofessionalization of library work by the Conservative federal government. In light of the controversial budget cuts and Code of Conduct issued by Library and Archives Canada, librarians and archivists across Canada mobilized in response. The LAC events exemplify the movement towards the commodification of information and privatization of the public sphere. LIAS scholars go beyond the LAC events to examine how neoliberalism is affecting librarianship with the growing disappearance of the professional library worker and increasing focus on the library user as a producer-consumer in planning documents, service models, and new library philosophies. The discourses of library association documents and library reports are often used as sources of data for researchers to highlight the language used that reinforces neoliberal ideologies. Work in this area also touches on how "public" public libraries are in the blurring lines between the public and private sphere. In response to the economic changes, many scholars are highlighting the importance of unions, advocacy and a political economy analysis of librarianship.

The plethora of independent archiving projects and the close relationship between archives and humanities have generated much literature on archives in Canada. Moving away from the view of archives as the storage of objective history, scholars have focused on the relationship between archives and power, and the growth of autonomous community archives. Legal records and immigration documents are critically examined in relation to mechanisms of exclusion and technologies of governance. The literature on community archives looks at specific archives, how they were formed, how they operate, and what they contribute to the greater public. Some examples of archives created include: a feminist porn archive, Canadian Women's Movement Archives, Canadian Lesbian and Gay Archives (CLGA), Missing and Murdered Indigenous Women Database (MMIWD), Sex Work Database (SWD), and Post-Apology Residential School Database (PARSD). A recurring conclusion in the literature is the need for more funding to sustain archiving projects. The literature demonstrates that many smaller archival projects are being supported through academic institutions. A strong theoretical line of thinking also pervades archival studies, focusing on the relationship between archival institutions and postmodernism. Some scholars have looked at how archival institutions have been and continue to be violent to Indigenous peoples even in responding to the TRC report and in the creation of NCTR. Archivists have exerted efforts to decolonize and deconstruct archives by rethinking archival description, and archival gaps. Another major area of interest in critical archival studies is the obsession with "the archive" in the humanities and the social sciences and how theorizations of the archive may divert from, support, and/or challenge the profession of archiving.

The literature on community-led librarianship, quite unique to Canada, branches from the Working Together Project, and the book Developing Community-Led Public Libraries: Evidence from the UK and Canada (Pateman \& Williment, 2016). Some of it serves to document community-led activities happening in Canada and highlights the marginalization of the poor and

Journal of Contemporary Issues in Education, 2020, 15(1), pp. 4-21. 
those who are homeless in public library settings. It advocates for intentional strategies and systematic action by public libraries to develop policies, programs, and spaces for the poor and critiques library policies that disproportionately cause harm to homeless people. Some special programs that are mentioned in the literature include: prison library programs and outreach programs with immigrants, adult literacy learners, and Aboriginal peoples.

In more recent years, there has been a rise in work on reconciliation and decolonization. Because of the sociopolitical context of Canada, Indigenous librarianship is a subject that stands out in Canadian literature on radical librarianship. Decolonizing library and archive institutions has become more of an urgent priority for many Canadian librarians after the release of the Truth and Reconciliation Report in 2015. The literature demonstrates how internship programs for Indigenous students have been established, courses on decolonizing information institutions have been developed, collection development has incorporated material by and for Indigenous peoples, and organization schemes have been reformed to fit Indigenous ways of knowing. Many scholars have recommendations for further transforming the field of librarianship in the process of reconciliation; such recommendations include honouring cultural protocol, practicing selfreflexivity, re-evaluating library collections and services, and taking direction from Indigenous peoples. Attention has also been given to why there are so few Indigenous libraries with the reasons being attributed to lack of funding for Indigenous communities, lack of financial resources and time for education, lack of knowledge of the profession, lack of job opportunities in their vicinity, the affective responses triggered by library institutions, low pay in Indigenous libraries, and issues of self-identification.

Unsurprisingly, analyses of race in Canada has been particularly lacking, with Aboriginal and Visible Minority Librarians: Oral Histories in Canada (see below), a book of the personal experiences of Indigenous and racialized librarians, standing in for much of that role. The literature on Indigenous and racialized librarianship in Canada has been written by the same few authors: Deborah Lee, Maha Kumaran, and David Hudson as there are few Indigenous and racialized librarians in Canada to begin with. A national survey was conducted by the Visible Minority Librarians of Canada in 2013 to gather data on demographics, needs and challenges facing visible minorities. The results demonstrate that more comprehensive data needs to be gathered on racial and ethnic diversity, institutional leadership and support needs to be more accessible to racial and ethnic minority librarians, better recruitment strategies need to be developed for increasing diversity in LIAS programs, and library associations in Canada must demonstrate greater leadership with respect to diversity. There is some scholarship done on the information needs of visible minorities, and the diversity of library collections and library services, but very little work on the library itself as an institution of racialization with the exception of David Hudson's work. In archival studies, a book called Identity Palimpsests: Archiving Ethnicity in the U.S. and Canada (2014) was published to focus on how ethnicity affects and is affected by archiving.

Journal of Contemporary Issues in Education, 2020, 15(1), pp. 4-21. 
The documentation of the historiography of radical librarianship in Canada is very scattered, and there lacks key texts that scholars of radical librarianship in Canada turn to. Empirical documentation rules over theoretical analyses in much of the work. Early history beyond the CLA is completely missing. For instance, the history of Emergency Librarian, an alternative library publication that was formed in 1973 in response to the frustrations towards CLA (Robbins, 1976, p. 2010), is near undocumented.

Other absences in the literature concern the geography of Canada, where there are few major cities and non-urban contexts are generally neglected. This absence creates a gap in understanding the issues that most affect rural and reserve settings. Because of the language divide, literature about or based in Quebec is also missing in the collection. The relatively sparse density of Canada results in few conversations happening across the national geography.

Another important group that has been largely absent from considerations of radical librarianship in Canada are transgender and gender-non-conforming populations (Lang, 2009). Lang argues that language to describe LGBTQ populations has been outdated in the profession and that gender identity is especially neglected in library discourse and practice. Gay and lesbian populations have received more attention, particularly in the school and medical library settings and in relation to Internet filtering and censorship.

From the literature review, what arises as gaps include: the early history of radical librarianship in Canada; geographic contexts outside major English-speaking cities; theoretical perspectives using critical theory; perspectives from Indigenous and racialized librarians and archivists; critical LIAS education and information literacy; social exclusion based on gender identity; critical work on homelessness and poverty; considerations of disability; and ties between librarianship, grassroots organizing and social movements in Canada. These silences are indicative of the persisting power relations that affect the library, archival and information setting. Carter's (2006) theorization of reading silence as a critical methodology is thus useful to think through the dependence of speech on silence and silence on speech. He cautions against abruptly filling in silences without careful consideration so that LIAS can pay closer attention to that which enables such silences in the first place. If LIAS literature is an essential space for critical reflection and contemplation, we must use this space to question the norms of the library and archival world, even in the spaces that seem themselves as more progressive.

\section{Conclusion}

This review, while showcasing the work on radical librarianship that is happening in Canada, is also a reflection on the state of critical LIAS. While the practice-driven focus of even LIAS literature is of course important for the profession, the sole attention to action-driven knowledge does not serve much. Thought must be conceived as a form of labour in and of itself for its ability to transform dominant epistemological paradigms and forms of knowledge production. If anything, librarians should understand the importance of thought and creating new ways of 
thinking. The intention of this paper is thus to encourage further inquiry into the subject of radical librarianship so as to continue nurturing these pockets of dissent. Continuous selfreflection and conceptual rethinking will strengthen LIAS scholarship and ensure that the profession is always aware of the dominant ideologies that pervade alternative library discourses and spaces.

\section{References}

Anderson, J. (2018, October 5). American democracy is fracturing. Libraries say they know now to help. Quartz. Retrieved from https:/qz.com/1401665/can-libraries-save-america/

Arkle, S., Brynolf, B., Clement, E., Corble, A., \& Redgate, J. (2016). Radical Librarians Collective: An overview. Post-Lib, 79, 2-5. Retrieved from http://www.academia.edu/36829809/Radical_Librarians_Collective_An_Overview

Bales, S. (2017). Social justice and library work: A guide to theory and practice. Chandos Publishing.

Beckman, M., Dahms, M., \& Bruce, L. (2006). Libraries. The Canadian Encyclopedia. Retrieved from https://www.thecanadianencyclopedia.ca/en/article/libraries

Birdsall, W. F. (2006). A progressive librarianship for the twenty-first century. Progressive Librarian, 28, 49-63. Retrieved from http://www.progressivelibrariansguild.org/PL/PL28.pdf\#page=49

Buckland, M. (2008). Letter to the editor: Democratic theory in library information science. JASIST, 59(9), 1534. https://doi.org/10.1002/asi.20846

Burpee, L. J. (1908). Canadian libraries of long ago. Bulletin of the American Library Association, 2(5), 136-143. Retrieved from https://www.jstor.org/stable/25684762

Buschman, J. (2018). On democracy and libraries. The Library Quarterly, 88(1), 23-40. https://doi.org/10.1086/694871

Carter, R. G. (2006). Of things said and unsaid: Power, archival silences, and power in silence. Archivaria, 61, 215-233. Retrieved from https://archivaria.ca/index.php/archivaria/article/view/12541

Daniel, D., \& Levi, A. S. (Eds.). (2014). Identity Palimpsests: Archiving ethnicity in the US and Canada. Sacramento, CA: Litwin Books.

Edmonton Public Library. (2008). Community-led toolkit. Retrieved from https://epl.bibliocms.com/wp-content/uploads/sites/18/2015/08/EPL-Community-LedToolkit-Final-EXTERNAL-Web.pdf

Frohmann, B. (2004). Review of Dismantling the Public Sphere, by John Buschman. Progressive Librarian, 23, 75-86. Retrieved from http://www.progressivelibrariansguild.org/PL/PL23/075.pdf

Foucault, M. (1972). Archeology of knowledge (A.M. Sheridan Smith, Trans.). New York, NY: Tavistock Publications Limited.

Gray, S. W. (2012). Locating librarianship's identity in its historical roots of professional philosophies: Towards a radical new identity for librarians of today (and tomorrow).

Journal of Contemporary Issues in Education, 2020, 15(1), pp. 4-21. 
Library Associations and Institutions, 39(1), 37-44.

https://doi.org/10.1177/0340035212472946

Gregory, L., \& Higgins, S. (2013). Introduction. In S. Higgins \& L. Gregory (Eds.), Information literacy and social justice: Radical professional praxis (pp. 1-12). Sacramento, CA: Library Juice Press.

Halpern, S. (2018, February 23). Libraries are a space where everyone belongs. The Nation. Retrieved from https://www.thenation.com/article/libraries-are-a-space-where-everyonebelongs/

Hudson, D. (2012). Unpacking "information inequality": Toward a critical discourse of global justice in Library and Information Science. Canadian Journal of Information and Library Science, 36(3-4), 69-87. http://doi.org/10.1353/ils.2012.0010

Hudson, D. J. (2016). On critical librarianship \& pedagogies of the practical [video file]. University of Alberta. Retrieved from https://repository-arizonaedu.login.ezproxy.library.ualberta.ca/handle/10150/612654

Hudson, D. J. (2017). On "diversity" as anti-racism in library and information studies: A critique. Journal of Critical Library and Information Studies, 1(1), 1-36. https://doi.org/10.24242/jclis.v1i1.6

Kagan, A. (2018). Progressive Library Organizations update, 2013-2017. Journal of Radical Librarianship, 4, 20-52. Retrieved from https://journal.radicallibrarianship.org/index.php/journal/article/view/27/38

Klinenberg, E. (2018, September 8). To restore civil society, start with the library. The New York Times. Retrieved from https://www.nytimes.com/2018/09/08/opinion/sunday/civilsociety-library.html

Lang, M. (2009). Library rhetoric: The Canadian Library Association Statement of Diversity and Inclusion \& LGBTQ advocacy. Progressive Librarian, 32, 36-54. Retrieved from http://www.progressivelibrariansguild.org/PL/PL32/036.pdf

Lankes, R. D. (2016). The new librarianship field guide. Cambridge, MA: MIT Press.

Lawson, S. (2015). Editorial: Journal of Radical Librarianship. Journal of Radical Librarianship, $1,1-2$. Retrieved from https://journal.radicallibrarianship.org/index.php/journal/article/view/1/5

McNally, P. F. (1986). The historiography of Canadian library history, or mapping the mind of the Canadian past. Journal of Library History, 21(2), 445-455. Retrieved from https://www.jstor.org/stable/25541706?seq=1\#metadata_info_tab_contents

Morrone, M. (2014). Introduction. In M. Morrone (Ed.), Informéd agitation: Library and information skills in social justice movements and beyond (pp. 1-7). Sacramento, CA: Litwin Books.

Pateman, J. (2019, April 4). The last bastion of democracy. Open Shelf. Retrieved from http://open-shelf.ca/190404-the-last-bastion-of-democracy/

Pateman, J., \& Williment, K. (2016). Developing community-led public libraries: Evidence from the UK and Canada. Abingdon, UK: Routledge.

Journal of Contemporary Issues in Education, 2020, 15(1), pp. 4-21. 
Peel, B. (1982). Librarianship in Canada before 1952. Archivaria, 15, 78-85. Retrieved from https://archivariaca.login.ezproxy.library.ualberta.ca/index.php/archivaria/article/download/10971/11904

Picco, M. A. P. (2008). Quebec's public libraries: An overview of their history and current situation. Public Library Quarterly, 27(2), 139-150. http://doi.org/10.1080/01616840802114945

Popowich, A.S. (2007). The politics of public library history. Dalhousie Journal of Interdisciplinary Management, 3. Retrieved from https://ojs.library.dal.ca/djim/article/view/2007vol3Popowich/45

Robertson, T. (2007). Critical librarianship: An interview with Toni Samek. Retrieved from https://bclaifc.wordpress.com/2007/11/13/critical-librarianship-an-interview-with-tonisamek/

Robbins, J. (1976). Two in "The Movement;" A review of" Booklegger" \&" Emergency Librarian". Library Journal, 101(17), 2010-2014. Print.

Samek, T. (2001). Introducing intellectual freedom courses into the Canadian LIS curriculum. Feliciter, 1, 40-43. https://doi.org/10.7939/R3571820D

Samek, T. (2004). Internet and intention: An infrastructure for progressive librarianship. International Journal of Information Ethics, 2, 1-18. https://doi.org/10.7939/R3XP6VH1Z

Samek, T. (2007). Librarianship and human rights: A twenty-first century guide. Oxford, UK: Chandos Publishing.

vanden Heuvel, K. (2018). Want to defend democracy? Start with your public library. Retrieved from https://www.washingtonpost.com/opinions/want-to-defend-democracystart-withyour-public-library/2018/09/18/7addf05a-bab2-11e8-9812a389be6690af story.html?utm term $=$. a8fb90844abf

Wiegand, W. A. (2011). Main Street Public Library: Community places and reading spaces in the rural heartland, 1876-1956. Iowa City: University of Iowa Press

Working Together Project. (2008). Community led libraries toolkit. Retrieved from https://www.librariesincommunities.ca/resources/Community-Led_Libraries_Toolkit.pdf

Yoder, A. R. (2003). The cyborg librarian as interface: Interpreting postmodern discourse on knowledge construction, validation, and navigation within academic libraries. portal: Libraries and the Academy, 3(3), 81-392. http://doi.org/10.1353/pla.2003.0074

Zeman, M. (2018, October 22). Public libraries celebrate the democratic ideal. Public Libraries Online. Retrieved from http://publiclibrariesonline.org/2018/10/public-librariescelebrate-the-democratic-ideal/

\section{Appendix: Shortlist of Resources on Radical Librarianship}

Lee, D. (2017). Indigenous librarians: Knowledge keepers in the 21st century. The Canadian Journal of Native Studies, 37(1), 175-199. Retrieved from https://harvest.usask.ca/bitstream/handle/10388/8195/doc04551320170929135850\%20(2).pdf?se quence $=1$

Journal of Contemporary Issues in Education, 2020, 15(1), pp. 4-21. 
Lee traces the history of why Canada has so few Indigenous librarians and advocates for the importance of more Indigenous librarians in changing the knowledge preservation landscape in Canada. Until the $60 \mathrm{~s} / 70 \mathrm{~s}$, there were essentially no libraries in Indigenous communities. The lack of funding support is a major reason for the absence of libraries in Indigenous communities. From interviews with 27 Indigenous librarians, Lee lists other major barriers: lack of financial resources and time for education, lack of knowledge of the profession, lack of job opportunities in their vicinity, affective responses to library institutions, low pay in Indigenous libraries, and issues of self-identification. In the article, she also lists libraryrelated projects that have been essential to Indigenous research, including the Xwi7Xwa Library, the First Nation Information Connection, and the Indigenous Studies Panel, and the library work of Gene Joseph in the landmark case of Delgamuukw et al. vs. the Queen in 1997.

Cannon, B. (2013). The Canadian disease: The ethics of library, archives, and museum convergence. Journal of Information Ethics, 22(2), 66-89. https://doi.org/10.3172/JIE.22.2.66

This article describes the epidemic of converging libraries, archives, and museums (LAMs) into monolithic organizations in Canada. Cannon analyzes the justification discourses of this convergence, evaluating their merit, to conclude that this convergence, instituted in a topdown manner, is apart of the broader movement to corporatize the cultural sphere. To supplement his argument, he examines the threats to professional principles of libraries, archives, and museums that have resulted from convergence and the negative responses of working librarians, archivists and museum workers to convergence.

Oliphant, T., \& McNally, M. B. (2014). Professional decline and resistance: The case of Library and Archives Canada. Radical Teacher, 99, 54-61. https://doi.org/10.5195/rt.2014.105

This article overviews the Library and Archives Canada (LAC) crisis that affected the profession of librarianship in Canada, focusing on the casualization of labour, deprofessionalization of library work, privatization, and resistance by the workers. It situates the LAC crisis within the broader shifts advanced by the Conservative government to cut down on staff and commercialize services. Oliphant and McNally compare the response by CAUT, in contrast with CLA, to discuss about the challenges of speaking out.

Ghaddar, J. J. (2016). The spectre in the archive: Truth, reconciliation, and indigenous archival memory. Archivaria, 82(1), 3-26. Retrieved from https://muse.jhu.edu/article/687080/pdf

This article looks at two legal cases relating to the TRC and records, exploring how the erasure of Indigenous peoples from archives connects to the dispossession of their lands, resources and heritage. It grapples with the tension between recognition and oblivion through records preservation or destruction. Ghaddar argues that the incorporation of Indigenous peoples into the national archive works to transform national shame into national triumph. Despite attempts by the TRC for reconciliation, such attempts operate within the liberal politics of recognition; Indigenous peoples remain spectres of the archive, haunting the settler colonial memory.

Journal of Contemporary Issues in Education, 2020, 15(1), pp. 4-21. 
Brothman, B. (1993). The limits of limits: Derridean deconstruction and the archival institution. Archivaria, 36, 205-220. Retrieved from

https://archivaria.ca/index.php/archivaria/article/view/11945/12903

This article examines the treatment of archives by works in the volume Reading the Archive, focusing on how these works grapple with the boundaries between history and archives, fiction and history, fiction and archives, myth and archives, and myth and reality. It offers a textual reading of archives, employing Derridean deconstruction, to demonstrate the interminable play between myth and reality and more broadly, grasp where and how discourses and concepts live by putting them under the threat of decomposition. It questions the closed, well-defined originary space of the archive, opening it up to the archive as an artefact of communication, as a text for reading, and a contract to be deconstructed.

Warner, J. N. (2005). Africa in Canadian academic libraries: A continent's voices go missing. Social Justice, 32(4), 180-191. Retrieved from https://www.jstor.org/stable/29768343?seq=1

This article looks at the absence of African voices and perspectives from library collections at York University Libraries (YUL), at a university that prides itself on its diversity and houses one of the only African Studies programs in Canada. The researcher is an African Canadian academic librarian and social justice advocate that is interested in reasons behind YUL's lack of academic resources about Africa. She discusses the academic library's reliance on approval plans in building collections, in relation to the lack of diversity in publishers and material, and also considers the role of Eurocentric bias in determining what a book and journal should look like. She ends by asserting that librarians should be more proactive in combating the homogeneity of collections and the structural biases of global publishing scene.

Schrader, A. M., \& Wells, K. (2004). Queer perspectives on social responsibility in Canadian schools and libraries. School Libraries in Canada, 24(4), 8-37. Retrieved from https://search.proquest.com/openview/8a900c089f31c53d2a7e1bfd6fb7f508/1?pqorigsite $=$ gscholar \&cbl $=32982$

This article examines discrimination against LGBTQ youth populations in Canada, focusing specifically on verbal abuse at schools, and argues that educators and librarians have essential roles to play in combating homophobia in schools. Schrader and Wells go over the legislation and ethical frameworks that mandate Canadian educators and librarians to support LGBTQ populations, and list the ways in which the practices of educators and librarians diverge from these ethical principles, contributing to censorship and difficulty locating LGBTQ resources. They also include a selected LGBTQ educational resource list, with books for different age groups, professional resources, policy and curriculum development resources, books on censorship, and e-resources.

Hudson, D. J. (2017). The whiteness of practicality. In Schlesselman-Tarango, G. (Ed.), Topographies of whiteness: Mapping whiteness in LIS. Sacramento: Library Juice Press.

Journal of Contemporary Issues in Education, 2020, 15(1), pp. 4-21. 
This article takes on a theoretical approach to analysing libraries as an institution of racialization. Hudson examines the alignment of practicality in library work with whiteness, the liberalism of diversity discourse, the dualism of theory and practice, the norms of language, and the place of anti-racist work in and beyond libraries.

Stevenson, S. A. (2016). Immaterial labour, public librarians, and third-generation public libraries. New Library World, 117(3/4), 186-200. https://doi.org/10.1108/NLW-11-2015-0083

This article analyses the Ontario public library report, Third Generation Public Libraries: Visionary Thinking and Service Development in Public Libraries (to 2020) and Potential Application in Ontario, from a political economy perspective, looking at the deprofessionalization of the library worker, with the simultaneous growth of the prosumer. Stevenson examines the report to demonstrate the pervasiveness of technological innovation discourse in structuring an increasingly neoliberal library environment. She uses the concept of immaterial labour to map out labour processes in the library, to show the possible exploitative practices that are emerging in the library setting. She closes the article by arguing for a more critical approach to policy development that attends to discursive power, and more on-the-ground studies on the everyday work of the librarian and the value of the profession.

Sloniowski, L. (2016). Affective labor, resistance, and the academic librarian. Library Trends, 64(4), 645-666. Retrieved from https://muse.jhu.edu/article/622026/pdf

This article takes on a feminist reading of academic librarianship, examining the theorization of affective labour in humanities and social sciences. Sloniowski explores socialist feminist critiques of autonomist conceptions of immaterial labor, where emotional labour and care work are devalued in comparison to intellectual immaterial labor, and poststructural feminist critiques, where the essentialization of women and gender identity is further deconstructed. She states that the invisibilization library work can be rooted in these gendered histories and current division of labour in the post-Ford economy. She concludes by arguing that attention to the immaterial labor of librarianship can offer disruptions to the increasingly corporate university.

Cook, T. (2001). Fashionable nonsense or professional rebirth: postmodernism and the practice of archives. Archivaria, 51, 14-35. Retrieved from https://pdfs.semanticscholar.org/f9a5/0f70ec00c7f98172384e9625ac87811783f8.pdf

This article explores the relevance of postmodern thinking for archival practice, the weaknesses and strengths of postmodern analysis, and the effects of postmodern thought on archival practice. Such embrace can result in greater awareness of the diversity, ambiguity, and multiple identities of records creators, information systems, and archives users for archival practice.

Journal of Contemporary Issues in Education, 2020, 15(1), pp. 4-21. 
Allard, D., \& Ferris, S. (2015). Antiviolence and marginalized communities: knowledge creation, community mobilization, and social justice through a participatory archiving approach. Library Trends, 64(2), 360-383. Retrieved from https://muse.jhu.edu/article/610082/pdf

This article overviews the participatory archiving practices used to create the Digital Archives and Marginalized Communities Project (DAMC), at the University of Manitoba, which includes the Missing and Murdered Indigenous Women Database (MMIWD), the Sex Work Database (SWD), and the Post-Apology Residential School Database (PARSD). This digital archive project weaves Indigenous knowledges, feminist praxis, and anti-oppressive practices into the information, institutions, and systems in collaboration with communities. Allard and Shawna also emphasize the importance of archivists as activists in doing this kind of social justice work and advocate for incorporating feminist, antiviolence, and anticolonialism methodologies into their archival methods.

Freeman, L. M., \& Blomley, N. (2019). Enacting property: Making space for the public in the municipal library. Environment and Planning C: Politics and Space, 37(2), 199-218. https://doi.org/10.1177\%2F2399654418784024

This article looks at the library and its changing mandate through the lens of property. Freeman and Blomley examine the changes to the sleeping policy in the Edmonton Public Library in Alberta, Canada (2014-2015) to demonstrate the shifting and sometimes opposing ways in which librarians enact public property.

Kandiuk, M., \& Sonne de Torrens, H. M. (2015). Librarians in a litigious age and the attack on academic freedom. In A. Woodsworth \& W. D. Penniman (Eds.), Current Issues in Libraries, Information Science and Related Fields (pp. 3-45). Emerald Group Publishing Limited.

This article focuses on the history of academic freedom for academic librarians in Canada, relevant legislation, the impact of new technologies on academic freedom and recent attacks on academic freedom. It also discusses the results of a survey on experiences of academic freedom sent to Canadian academic librarians. The results revealed a lack of awareness and understanding on the part of Canadian academic librarians regarding their rights and protections with respect to academic freedom.

Dekker, J., \& Kandiuk, M. (2014). In solidarity: Academic librarian labour activism and union participation in Canada. Sacramento, CA: Library Juice Press.

This book is a collection of work on the unionization of academic librarians and labour issues faced by librarians. It fills an essential gap on academic librarian labour activism in Canada, touching on the history of organizing, academic status, collective bargaining, leadership in academic staff associations, and recent attacks to the academic librarian profession.

Lee, D., \& Kumaran, M. (Eds.). (2014). Aboriginal and visible minority librarians: Oral histories from Canada. Lanham, MD: Rowman \& Littlefield.

This book showcases the experiences of Indigenous librarians and librarians of colour in Canada, mostly those who immigrated from outside of Canada, the challenges they face in 
the field, and recommendations for combating barriers. These librarians emphasize feelings of isolation/alienation, tokenism, lack of support, and microaggressions as major challenges, and advocate for more support networks, mentorship opportunities, and professional development as future directions in the field. 